\title{
Evaluasi Performansi dan Tingkat Kelelahan dalam Upaya Optimisasi Capaian Pembelajaran Sistem Praktikum di Perguruan Tinggi $X$
}

\author{
Asterina Febrianti, Lauditta Irianti, Aldila Hasanah \\ Jurusan Teknik Industri, Fakultas Teknik Industri, ITENAS, Bandung \\ Email: febrianti.asterina@gmail.com
}

\begin{abstract}
ABSTRAK
Praktikum merupakan sebuah proses pengamatan, percobaan, dan pengujian terhadap materi mata kuliah yang didapatkan. Praktikum diadakan sebagai salah bentuk pencapaian proses pembelajaran suatu mata kuliah. Satu sks terdiri dari 170 menit pembelajaran perminggu dalam satu semester untuk aktivitas praktikum. Aktivitas praktikum dilaksanakan selama 120 menit dan sisanya disebut tugas mandiri sebanyak 50 menit. Pada kenyataannya tugas mandiri yang dilaksanakan mahasiswa lebih dari 50 menit dalam 1 minggu. Mahasiswa sering terlihat mengalami penurunan performansi dalam aktivitas perkuliahan disertai dengan munculnya kondisi kelelahan. Kondisi tersebut sangat mempengaruhi beban kerja mental mahasiswa dalam beraktivitas, sehingga tujuan penelitian ini adalah untuk mengevaluasi sistem praktikum berdasarkan beban kerja mental melalui pengukuran performansi dan kelelahan di perguruan Tinggi X. Pengukuran tingkat performansi (waktu reaksi) menggunakan psychomotor vigilance test (PVT) dengan parameter mean 1/RT, shortest 10\% 1/RT, lapses, dan longest 10\% 1/RT, serta kelelahan menggunakan kuesioner visual analog scale (VAS). Pengukuran dilakukan setelah praktikum, sebelum asistensi laporan, dan sebelum presentasi laporan. Uji statistik menunjukan untuk parameter performansi yaitu shortest 10\% 1/RT signifikan medeteksi perubahan untuk ketiga kondisi, sementara untuk mean 1/RT, lapses, dan longest 1/RT tidak signifikan dalam mendeteksi perubahan waktu reaksi untuk ketiga kondisi tersebut. Parameter VAS juga menunjukan hasil tidak signifikan dalam perubahan kondisi kelelahan untuk ketiga kondisi tersebut. Hasil menunjukan bahwa mahasiswa tidak mengalami peningkatan beban kerja mental saat melewati rangkaian proses praktikum di jurusan teknik industri pada perguruan tinggi $X$, sehingga sistem praktikum yang diterapkan saat ini dalam pencapaian proses pembelajaran sudah optimal.
\end{abstract}

Kata kunci: waktu reaksi, kelelahan, PVT, VAS.

\begin{abstract}
Practicum are observation, experiment, and examination towards the obtained course material. Practicum held as a form of achievement learning process of a course. One course credit (sks) has 170 minutes learning once a week witihin a semester dedicated for practicum activity. Practicum activity consists of 120 minutes actual practice and 50 minutes independent task. In fact, independent task occurs over 50 minutes once a week. Many Students have seen their academics performances decline, along with fatigue because of the practice activity while also attending lectures in classes. These Conditions often affected students mental workload, which is why the aim of this study is to evaluate practicum activity system based on mental workload through measurement of perfomance and fatigue on college X. Measurement performance rate (reaction time) use psychomotor vigilance test (PVT) with parameter mean 1/RT, shortest 10\% 1/RT, lapses, and longest $10 \%$ $1 / R T$, with questionnaire visual analog scale (VAS) for fatigue measurement. Each measurement was made after practicum, before assistance report, and before a report presentation. Statistics showed shortest $10 \%$ $1 / R T$ significant detecting transformation for third condition, while mean $1 / R$, lapses, and longest $10 \%$ were not significant. VAS parameter showed not significant result in term of detecting transformation for those 3 condition mentioned berofe. Result showed mental workload through series of practicum activity at Industrial Engineering Major on college X are not significant, which is showed that the current practicum system activity for achievement learning process are optimum.
\end{abstract}

Keywords: reaction time, fatigue, PVT, VAS. 


\section{PENDAHULUAN}

Aktivitas belajar mengajar pada perkuliahan di sebuah perguruan tinggi biasanya didukung dengan aktivitas praktikum. Perguruan tinggi $X$ merupakan salah satu perguruan tinggi swasta di Bandung yang mendukung rangkaian proses praktikum untuk memenuhi aktivitas perkuliahannya. Praktikum diadakan sebagai salah bentuk pencapaian proses pembelajaran suatu mata kuliah. Praktikum merupakan sebuah proses pengamatan, percobaan, dan pengujian terhadap materi mata kuliah yang didapatkan. Menurut Peraturan Menteri Pendidikan dan Kebudayaan Republik Indonesia Nomor 44 tahun 2015 Pasal 14 Ayat 5, bentuk pembelajaran terdiri dari kuliah, responsi/tutorial, seminar dan praktikum/studi/bengkel/lapangan. Sistem perkuliahan di Perguruan Tinggi X mengacu kepada peraturan Menteri Pendidikan dan Kebudayaan mengenai aturan Satuan Kredit Semester (sks). Satu sks terdiri dari 170 menit pembelajaran perminggu dalam satu semester untuk aktivitas praktikum. Jurusan teknik industri merupakan salah satu jurusan di perguruan tinggi $\mathrm{X}$ yang mendukung aktivitas praktikum dalam proses perkuliahannya. Aktivitas praktikum dilaksanan di setiap semester baik ganjil maupun genap dengan jenis praktikum yang berbeda-beda dari semester 1 hingga semester 7. Setiap praktikum biasanya terdiri dari kurang lebih 6 sampai 7 modul yang harus diselesaikan. Aktivitas praktikum dilaksanakan selama 120 menit dan sisanya disebut tugas mandiri sebanyak 50 menit. Tugas mandiri biasanya berupa laporan yang terdiri dari bab 1 hingga bab 6 yang harus dikerjakan dan dikumpulkan kurang lebih dengan interval waktu satu minggu. Selama satu minggu terdapat beberapa rangkaian tugas mandiri yang dilakukan yaitu asistensi draft laporan, pengumpulan laporan, dan presentasi laporan.

Akibat adanya tugas mandiri tersebut banyak keluhan yang dirasakan mahasiswa bahwa praktikum lebih banyak menyita waktu ketimbang proses perkuliahan di kelas pada umumnya. Banyak pihak termasuk dosen yang merasakan bahwa performansi mahasiswa mengalami penurunan dalam aktivitas perkuliahan di kelas. Penurunan performansi erat kaitannya dengan penurunan tingkat kewaspadaan seseorang [1]. Tingkat kewaspadaan menurun biasa diakibatkan oleh keterlambatan seseorang merespon sesuatu. Waktu reaksi merupakan kecepatan manusia dalam merespon suatu rangsangan [2]. Sehingga penurunan performansi dapat dilihat dari waktu reaksi seseorang dalam merespons sesuatu. Efek yang dirasakan oleh mahasiswa selain adanya penurunan performansi ialah peningkatan kondisi kelelahan. Mahasiswa sering terlihat kurang fokus dan cepat lelah saat proses perkuliahan berlangsung. Tingkat kewaspadaan menurun dapat meningkatkan kondisi kelelahan pada suatu individu [3]. Penurunan performansi dan peningkatan kondisi kelelahan menunjukan bahwa beban kerja seseorang meningkat. Beban kerja dapat didefinisikan sebagai konstruk mental yang mencerminkan ketegangan mental yang dihasilkan dari melakukan suatu pekerjaan berdasarkan kemampunan manusia, kondisi lingkungan dan operasional tertentu [4]. Melihat dari aktivitasnya, rangkaian proses praktikum diklasifikasikan menjadi beban kerja mental. Beban kerja mental adalah perbedaan antara kapasitas sistem pengolahan informasi manusia yang diperlukan suatu pekerjaan untuk dapat memenuhi performansi yang diharapkan [4]. Berdasarkan permasalahan tersebut, maka diperlukan penelitian untuk mengevaluasi performansi dan tingkat kelelahan sistem praktikum berdasarkan beban kerja mental melalui pengukuran performansi dan kelelahan untuk optimisasi capaian proses pembelajaran sistem praktikum jurusan teknik industri di perguruan tinggi X.

\section{METODOLOGI}

\subsection{Partisipan}

Jurusan Teknik Industri di Perguruan Tinggi X memiliki 12 jenis praktikum. saat ini pengambilan data dilakukan pada semester genap yang terdiri dari beberapa jenis praktikum yaitu; Fisika Dasar II \& Bahasa Inggris II (semester 2), Statistika Industri (semester 4), dan Perancangan dan Pengendalian Produksi II \& Otomasi Industri (semester 6). Jenis praktikum yang dipilih dengan melihat Indeks Prestasi Semester (IPS) terendah pada angkatan 2011, 2012, dan 2013. Hasil menunjukan IPS terendah terdapat pada semester 6 . Selanjutnya memilih 2 jenis praktikum yang dipilih dari semester 6 dengan cara melihat nilai praktikum terendah. Praktikum terpilih dengan nilai terendah yaitu praktikum Perancangan dan Pengendalian Produksi II. 
Partisipan pada penelitian ini ialah mahasiswa angkatan 2014 Jurusan Teknik Industri yang sedang mengambil praktikum Perancangan dan Pengendalian Produksi II. Jumlah SKS yang diambil partisipan ialah jumlah SKS normal setiap satu semester yaitu 18-20 sks untuk menghindari bias saat pengambilan data dan untuk menghidari beban kerja berlebih. Jumlah partisipan dihitung dengan rumus penelitan eksperimental berikut ini [5]:

$(\mathrm{t}-1)(\mathrm{r}-1) \geq 15$

$(3-1)(\mathrm{r}-1) \geq 15$

$\mathrm{r} \geq 8,5 \approx 9$ Orang

Keterangan:

$\mathrm{t}=$ banyak kelompok perlakuan

$\mathrm{r}=$ jumlah replikasi

\subsection{Prosedur Penelitian}

Prosedur penelitian terdiri dari persiapan penelitian dan prosedur pengambilan data. Persiapan penelitian adalah hal yang harus dipersiapkan partisipan sebelum proses pengambilan data, diantaranya adalah:

1. Tidak sedang memiliki masalah kesehatan fisik maupun mental (untuk menghindari pengaruh dari obat atau pengobatan yang sedang dijalani) [6].

2. Tidak merokok, minum alkohol, minum kopi, beraktivitas fisik, dan minum soft drink satu jam sebelum pengukuran [7].

Sementara prosedur pengambilan data terdiri dari hari persiapan dan proses pengumpulan data. Hari persiapan merupakan aktivitas pengenalan terhadap alat ukur terhadap partisipan agar partisipan dapat beradaptasi terhadap alat ukur dengan baik serta untuk mengurangi bias saat pengambilan data. Proses pengambilan data dilakukan dengan 3 kondisi yaitu saat setelah pelaksanaan praktikum, sesaat sebelum melakukan asistensi laporan praktikum, dan sesaat sebelum melakukan presentasi laporan. Pengukuran dilakukan terhadap 3 modul praktikum yaitu modul awal, modul tengah, dan modul akhir.

\subsection{Tempat dan Alat Penelitian}

Penelitian dilakukan pada saat rangkaian praktikum Perancangan dan Pengendalian Produksi II jurusan Teknik Industri di Perguruan Tinggi X dengan mendatangi mahasiswa secara langsung. Alat yang digunakan untuk pengukuran ialah Psychomotor Vigilance Task (PVT) dan kuesioner Visual Analog Scale (VAS).

\subsection{Penentuan Metode Penelitian}

Evaluasi beban kerja mental diukur menggunakan parameter performansi dan kelelahan saat rangkaian proses praktikum. Evaluasi performansi kerja dapat dilihat menggunakan waktu reaksi. Pengukuran waktu reaksi dengan Psychomotor Vigilance Task (PVT) dapat menggunakan perangkat lunak Reaction Time V4.03. Proses pengambilan data menggunakan perangkat lunak Reaction Time V4.03 partisipan diminta untuk memperhatikan layar komputer dan menekan tombol spasi pada keyboard pada saat muncul gambar persegi panjang berukuran 5,687 x 3,254 $\mathrm{cm}$ berwarna merah pada layar dengan latar belakang berwarna hijau. Evaluasi tingkat kelelahan menggunakan kuesioner Visual Analog Scale (VAS). Kuesioner VAS merupakan garis horizontal sepanjang $100 \mathrm{~mm}$ yang menggambarkan 2 kata ekstrim di setiap ujung garis [2]. Kuesioner VAS ini digunakan karena penggunaannya yang mudah dan tidak banyak menyita waktu partisipan saat mengisinya, serta partisipan hanya perlu menyematkan garis tegak sepanjang $100 \mathrm{~mm}$.

\subsection{Uji Statistik}

Penelitian ini merupakan eksperimen within subject dimana setiap partisipan menerima keseluruhan perlakuan. Uji statistik dilakukan pada parameter PVT yaitu mean 1/RT, shortest 10\% 1/RT, lapses dan longest 10\% 1/RT, serta parameter VAS dengan menggunakan uji friedman dan uji korelasi. Uji friedman dilakukan untuk melihat apakah terdapat perbedaan antara ketiga kondisi yang diberlakukan (setelah praktikum, sebelum asistensi, dan sebelum presentasi). Uji korelasi menggunakan uji spearman rho dilakukan untuk mengetahui keterkaitan antara tingkat performansi dan kelelahan pada mahasiswa di perguruan tinggi $X$. Tingkat kepercayaan yang digunakan ialah $10 \%$, hal ini dikarenakan 
penelitian bersifat langsung dilapangan dan ada beberapa variabel yang tidak bisa dikontrol secara ketat.

\subsection{Pengolahan Data}

Pengolahan data terdiri dari pengolahan data psychomotor vigilance test (PVT), visual analog scale (VAS), dan uji korelasi parameter performansi dan kelelahan.

\subsubsection{Psychomotor Vigilance Task (PVT)}

Pengolahan data waktu reaksi dibagi ke dalam 4, yaitu mean 1/RT, shortest $10 \% 1 / \mathrm{RT}$, lapses dan longest $10 \% 1 / \mathrm{RT}$.

\section{1) Mean $1 / \mathrm{RT}$}

Hasil presentase data mean 1/RT pada Tabel 1 menunjukan bahwa kondisi setelah praktikum mengalami peningkatan kewaspadaan sebesar 18,09\% dibandingkan dengan kondisi sebelum asistensi yaitu sebesar $17,62 \%$ dan kondisi sebelum presentasi yaitu sebesar 18,01\%. Pola sebaran data waktu reaksi mean 1/RT dapat dilihat pada Gambar 1.

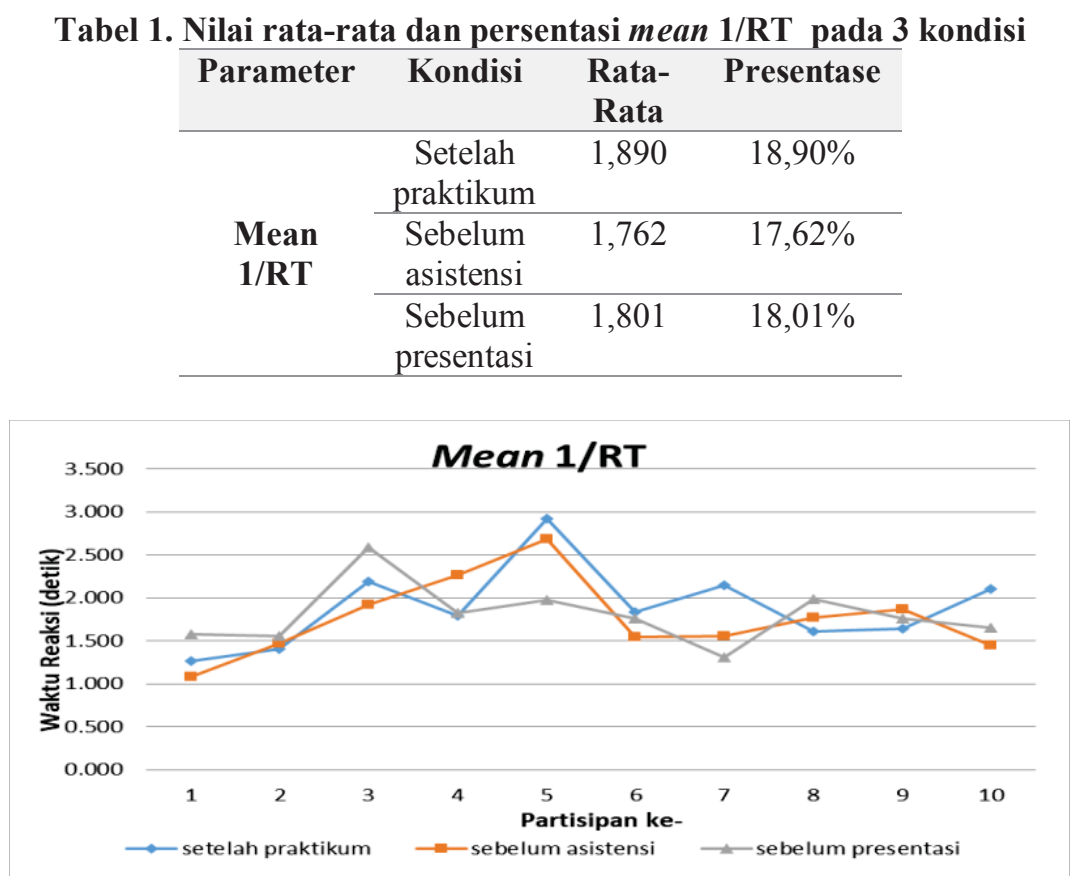

Gambar 1. Grafik data waktu reaksi mean 1/RT setiap kondisi

Jika dilihat pada Gambar 1 bahwa nilai mean 1/RT pada saat sebelum asistensi lebih rendah jika dibandingkan kedua kondisi lainnya, sedangkan nilai tertinggi dihasilkan saat setelah praktikum. Hal ini menunjukkan bahwa berdasarkan parameter mean 1/RT bahwa rata-rata partisipan merasa paling waspada setelah aktivitas praktikum dan rata-rata kewaspadaan terendah terjadi sebelum asistensi laporan.

\section{2) Shortest $10 \% 1 / \mathrm{RT}$}

Hasil presentase data shortest 10\% 1/RT pada Tabel 2 menunjukan bahwa kondisi setelah praktikum mengalami peningkatan kewaspadaan sebesar 32,45\% dibandingkan dengan kondisi sebelum asistensi yaitu sebesar $29,23 \%$ dan kondisi sebelum presentasi yaitu sebesar $30,49 \%$. Pola sebaran data waktu reaksi shortest 10\% 1/RT dapat dilihat pada Gambar 2. 
Tabel 2. Nilai rata-rata dan persentasi shortest $10 \% 1 / \mathrm{RT}$ pada 3 kondisi

\begin{tabular}{cccc}
\hline Parameter & Kondisi & $\begin{array}{c}\text { Rata- } \\
\text { Rata }\end{array}$ & Presentase \\
\hline & $\begin{array}{c}\text { Setelah } \\
\text { praktikum }\end{array}$ & 3,245 & $32,45 \%$ \\
\cline { 2 - 4 } Shortest & $\begin{array}{c}\text { Sebelum } \\
\text { 10\% 1/RT }\end{array}$ & 2,923 & $29,23 \%$ \\
\cline { 2 - 4 } & $\begin{array}{c}\text { Sebistensi } \\
\text { pebelum }\end{array}$ & 3,049 & $30,49 \%$ \\
\hline
\end{tabular}

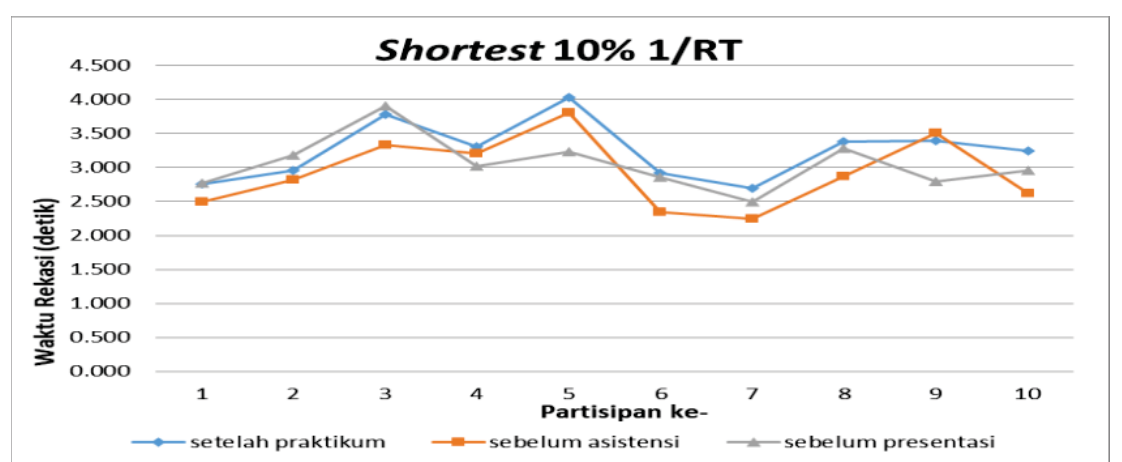

Gambar 2. Grafik data waktu reaksi shortest 10\% 1/RT setiap kondisi

Jika dilihat pada Gambar 2 bahwa nilai shortest 10\% 1/RT pada saat sebelum asistensi lebih rendah jika dibandingkan kedua kondisi lainnya, sedangkan nilai tertinggi dihasilkan saat setelah praktikum. Hal ini menunjukkan bahwa berdasarkan parameter shortest 10\% 1/RT bahwa rata-rata partisipan merasa paling waspada setelah aktivitas praktikum dan rata-rata kewaspadaan terendah terjadi sebelum asistensi laporan.

\section{3) Lapses}

Hasil presentase data Shortest 10\% 1/RT pada Tablel 3 menunjukan bahwa kondisi setelah praktikum mengalami peningkatan kewaspadaan sebesar $204,00 \%$ dibandingkan dengan kondisi sebelum asistensi yaitu sebesar 265,00\% dan kondisi sebelum presentasi yaitu sebesar 234,00\%. Pola sebaran data waktu reaksi lapses dapat dilihat pada Gambar 3.

Tabel 3. Nilai rata-rata dan persentasi lapses pada 3 kondisi

\begin{tabular}{cccc}
\hline Parameter & Kondisi & $\begin{array}{c}\text { Rata- } \\
\text { Rata }\end{array}$ & Presentase \\
\hline \multirow{4}{*}{ Lapses } & $\begin{array}{c}\text { Setelah } \\
\text { praktikum }\end{array}$ & 20,40 & $204,0 \%$ \\
\cline { 2 - 4 } & $\begin{array}{c}\text { Sebelum } \\
\text { asistensi }\end{array}$ & 26,50 & $265,0 \%$ \\
\cline { 2 - 4 } & $\begin{array}{c}\text { Sebelum } \\
\text { presentasi }\end{array}$ & 23,40 & $234,0 \%$ \\
\hline
\end{tabular}




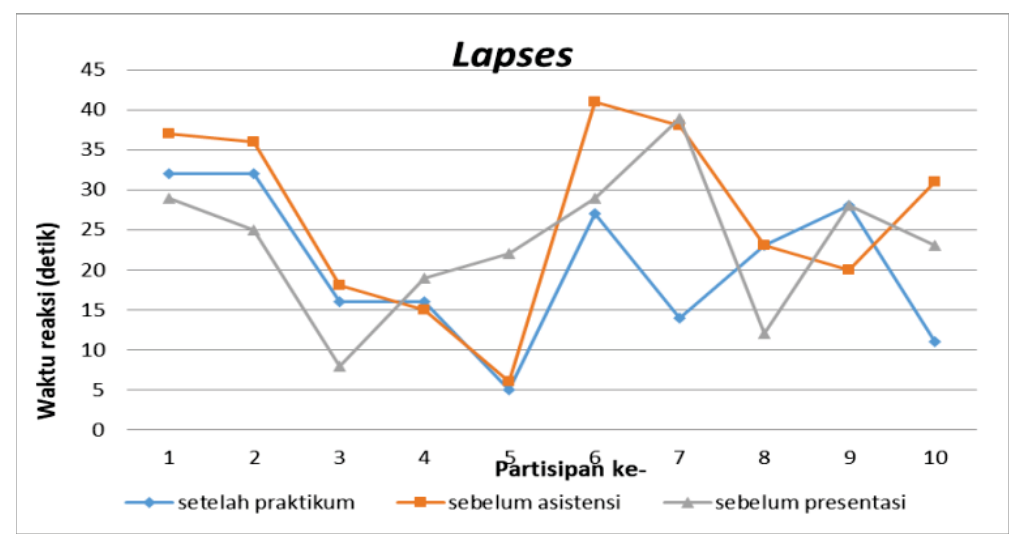

Gambar 3. Grafik data waktu reaksi lapses setiap kondisi

Jika dilihat pada Gambar 3 bahwa nilai lapses pada saat sebelum asistensi paling tinggi jika dibandingkan kedua kondisi lainnya, sedangkan nilai lapses terendah dihasilkan saat setelah praktikum. Hal ini menunjukkan bahwa berdasarkan parameter lapses bahwa rata-rata partisipan merasa paling waspada setelah aktivitas praktikum dan rata-rata kewaspadaan terendah terjadi sebelum asistensi laporan.

\section{4) Longest $10 \% 1 / \mathrm{RT}$}

Hasil presentase data Longest 10\% 1/RT pada Tablel 4 menunjukan peningkatan kewaspadaan sebesar $12,16 \%$ dibandingkan dengan kondisi sebelum asistensi yaitu sebesar 9,80\% dan kondisi sebelum presentasi yaitu sebesar 9,51\%. Pola sebaran data waktu reaksi Longest 10\% 1/RT dapat dilihat pada Gambar 4.

\begin{tabular}{|c|c|c|c|}
\hline Parameter & Kondisi & $\begin{array}{l}\text { Rata- } \\
\text { Rata }\end{array}$ & Presentase \\
\hline \multirow{3}{*}{$\begin{array}{c}\text { Longest } \\
10 \% \text { 1/RT }\end{array}$} & $\begin{array}{c}\text { Setelah } \\
\text { praktikum }\end{array}$ & 1,216 & $12,16 \%$ \\
\hline & $\begin{array}{l}\text { Sebelum } \\
\text { asistensi }\end{array}$ & 0,980 & $98,0 \%$ \\
\hline & $\begin{array}{l}\text { Sebelum } \\
\text { presentasi }\end{array}$ & 0,951 & $95,1 \%$ \\
\hline
\end{tabular}

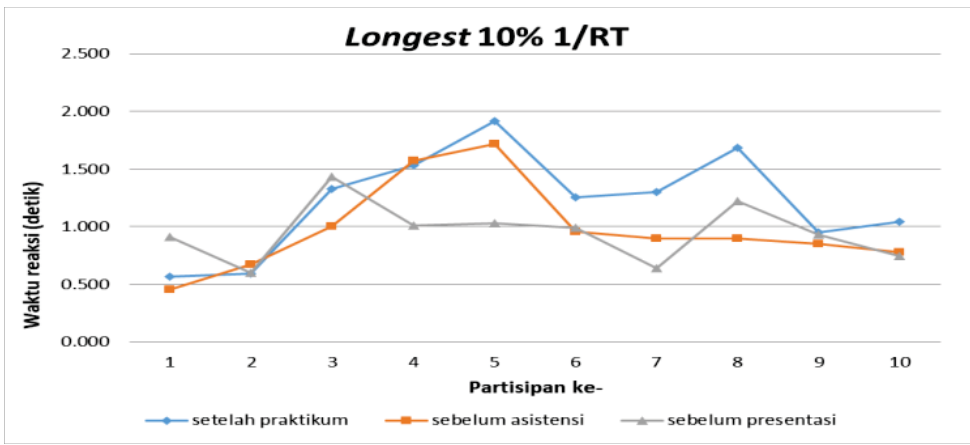

Gambar 4. Grafik data waktu reaksi longest $10 \%$ 1/RT setiap kondisi

Jika dilihat pada Gambar 4 bahwa nilai longest 10\% 1/RT pada saat sebelum presentasi lebih rendah jika dibandingkan kedua kondisi lainnya, sedangkan nilai tertinggi dihasilkan saat setelah praktikum. Hal ini menunjukkan bahwa berdasarkan parameter longest 10\% $1 /$ RT bahwa rata-rata partisipan merasa paling waspada setelah aktivitas praktikum dan rata-rata kewaspadaan terendah terjadi sebelum presentasi laporan. 


\subsubsection{VAS}

Hasil presentase data VAS pada Tablel 5 menunjukan bahwa kondisi setelah praktikum mengalami peningkatan kelelahan sebesar $51.08 \%$ dibandingkan dengan kondisi sebelum asistensi yaitu sebesar $48.72 \%$ dan kondisi sebelum presentasi yaitu sebesar $41.32 \%$. Pola sebaran visual analog scale (VAS) dapat dilihat pada Gambar 5.

Tabel 5. Nilai rata-rata dan persentasi VAS pada 3 kondisi

\begin{tabular}{cccc}
\hline Parameter & Kondisi & $\begin{array}{c}\text { Rata- } \\
\text { Rata }\end{array}$ & Presentase \\
\hline \multirow{4}{*}{ VAS } & $\begin{array}{c}\text { Setelah } \\
\text { praktikum }\end{array}$ & 5,108 & $51,08 \%$ \\
\cline { 2 - 4 } & $\begin{array}{c}\text { Sebelum } \\
\text { asistensi }\end{array}$ & 4,872 & $48,72 \%$ \\
\cline { 2 - 4 } & $\begin{array}{c}\text { Sebelum } \\
\text { presentasi }\end{array}$ & 4,132 & $41,32 \%$ \\
\hline
\end{tabular}

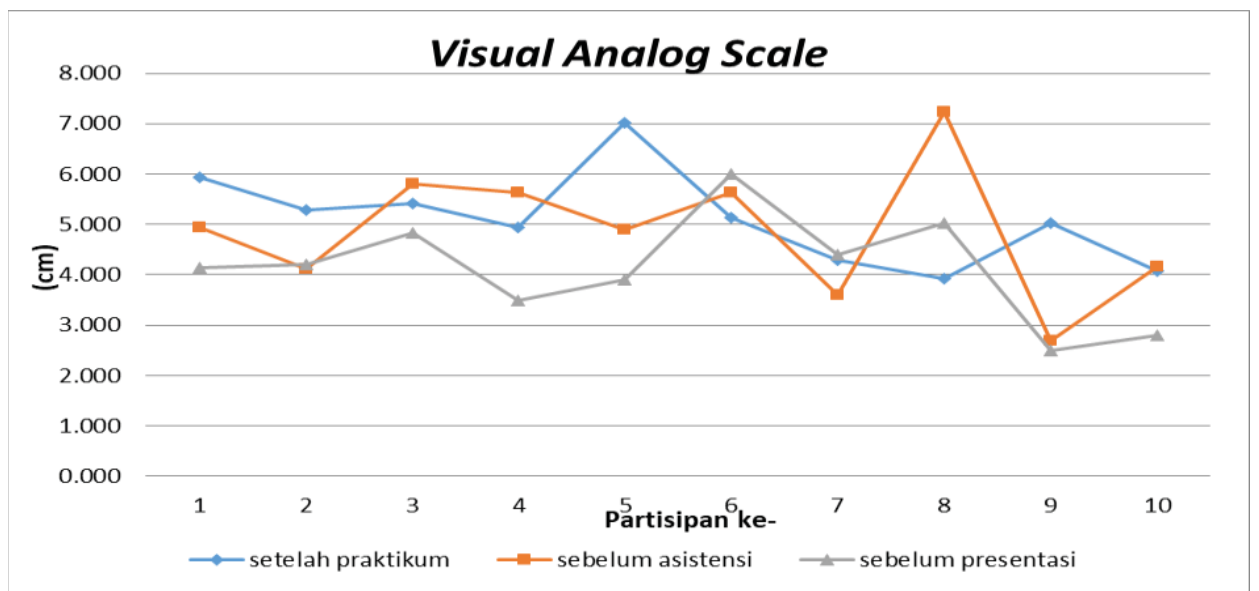

Gambar 5. Grafik Data Visual Analog Scale Setiap Kondisi

Berdasarkan Gambar 5 menunjukkan bahwa nilai kuesioner Visual Analog Scale (VAS) memiliki rata-rata kelelahan tertinggi saat setelah praktikum dan rata-rata partisipan merasakan tingkat kelelahan terendah saat sebelum presentasi.

\subsubsection{Rekapitulasi Hasil Pengujian Statistika}

Berdasarkan hasil pengolahan data secara keseluruhan maka terdapat hasil rekapitulasi uji friedman yang dapat dilihat pada Tabel 6 . Hasil menunjukan bahwa parameter longest $10 \%$ 1/RT terdapat perbedaan waktu reaksi yang signifikan antar kondisi. Sementara untuk parameter lainnya tidak terdapat perbedaan yang signifikan antar kondisi. Parameter VAS juga menunjukan hasil yang tidak signifikan atau tidak terjadi peningkatan kondisi kelelahan yang signifikan antar kondisi. Tabel 7 menunjukan terdapat korelasi yang kuat antara variabel PVT dengan VAS namun hasil menunjukan bahwa korelasi yang terjadi tidak signifikan. 
Tabel 6. Rekapitulasi uji friedman untuk setiap alat ukur

\begin{tabular}{lcc}
\multicolumn{1}{c}{ Parameter } & \multicolumn{2}{c}{ 5-Min PVT } \\
\cline { 2 - 3 } & $\chi^{2}(2,10)$ & $P^{\mathrm{a}}$ \\
\hline Mean 1/RT & 0.8 & 0.679 \\
\hline $\begin{array}{l}\text { Shortest 10\% } \\
\text { 1/RT }\end{array}$ & 7.2 & 0.027 \\
\hline $\begin{array}{l}\text { Longest 10\% } \\
\text { 1/RT }\end{array}$ & 3.8 & 0.15 \\
\hline Lapses & 2.513 & 0.285 \\
\hline \multicolumn{1}{c}{ Paramater } & $\boldsymbol{\chi}^{\mathbf{2}} \mathbf{( 2 , 1 0 )}$ & $\boldsymbol{P}^{\mathbf{a}}$ \\
\hline VAS & 2,4 & 0.301 \\
\hline
\end{tabular}

Tabel 7. Rekapitulasi uji korelasi paramter alat ukur

\begin{tabular}{lcc}
\multicolumn{1}{c}{ Parameter } & \multicolumn{2}{c}{ VAS } \\
\cline { 2 - 3 } Mean 1/RT & $\boldsymbol{\rho}$ & $\boldsymbol{P}^{\mathbf{a}}$ \\
\hline $\begin{array}{l}\text { Shortest 10\% } \\
\text { 1/RT }\end{array}$ & -0.5 & 0.667 \\
\hline $\begin{array}{l}\text { Longest 10\% } \\
\text { 1/RT }\end{array}$ & -0.5 & 0.667 \\
\hline Lapses & -0.5 & 0.667 \\
\hline
\end{tabular}

\section{HASIL DAN PEMBAHASAN}

Uji statistika friedman menghasilkan nilai signifikan untuk parameter shortest $10 \% 1 / \mathrm{RT}\left(\mathrm{p}^{\mathrm{a}}\right.$ $=0.027<\alpha=0.1)$, sementara untuk parameter mean $1 / \mathrm{RT}\left(\mathrm{p}^{\mathrm{a}}=0.679>\alpha=0.1\right)$, longest $10 \% 1 / \mathrm{RT}\left(\mathrm{p}^{\mathrm{a}}=0.150>\alpha=0.1\right)$, lapses $\left(\mathrm{p}^{\mathrm{a}}=0.285>\alpha=0.1\right)$, dan VAS $\left(\mathrm{p}^{\mathrm{a}}=0.301>\alpha=\right.$ 0.1 ) tidak menunjukan hasil yang signifikan. Parameter shortest $10 \% 1 / \mathrm{RT}$ menunjukan bahwa terdapat perbedaan waktu reaksi antar ketiga kondisi yang signifikan, sementara untuk parameter mean 1/RT, longest 10\% 1/RT, dan lapses masih terdapat perbedaan waktu reaksi antara ketiga kondisi namun tidak signifikan. Hal tersebut menunjukan bahwa parameter PVT kurang kuat dalam mendeteksi perubahan waktu reaksi untuk ketiga kondisi tersebut. Sementara parameter VAS juga menunjukan bahwa tidak terdapat perbedaan tingkat kelelahan yang signifikan antara ketiga kondisi. Uji korelasi menunjukkan bahwa antara parameter PVT (mean 1/RT, shortest 10\% 1/RT, longest 10\% 1/RT, dan lapses) dengan parameter VAS terdapat hubungan yang kuat namun tidak signifikan $\left(\rho=-0.5, \mathrm{p}^{\mathrm{a}}=0.667\right)$.

\section{KESIMPULAN}

Hasil menunjukan bahwa baik untuk parameter performansi maupun parameter kelelahan tidak signifikan dalam mendeteksi perubahan waktu reaksi maupun kelelahan pada kondisi setelah praktikum, sebelum asistensi, dan setelah presentasi. Hal tersebut menunjukan bahwa mahasiswa tidak mengalami peningkatan beban kerja mental yang signifikan akibat rangkaian kegiatan praktikum. Proses pembelajaran praktikum selama 120 menit di laboratorium dan tugas mandiri selama 50 menit dirasa masih cukup baik. Oleh karena itu sistem praktikum yang diterapkan saat ini guna proses capaian pembelajaran sudah optimal.

\section{DAFTAR PUSTAKA}

[1] Lal, S.K.L. (2001). The psychophysiology of driver fatigue/drowsiness: Electroencelophalography, electro-oculogram, electrocardiogram and psychological effects.

[2] Johns, M. W. (2009). What is excessive daytime sleepiness?. in sleep deprivation: causes, effects and treatment. Australia: Nova Science Publishers, Inc. 
[3] Lal, S.K.L, Craig, A. (2001). A critical review of the psychophysiology of driver fatigue. Biological Psychology, 55: 173-194.

[4] Omolayo, B.O dan Omole, O.C. (2013). Influence of mental workload on job performance. International Journal of Humanities and Social Science, 3 (15), 238-246.

[5] Supranto, J. (2000). Statistik teori dan aplikasi jilid 1. Jakarta: Erlangga.

[6] Kaida, K., Takahashi, M., Akestedt, T., Nakata, A., Otsyka, T., Haratani, T., dkk. (2006). Validation of karolinska sleepness scale against performance and EEG variables. Clinical Neurophysiology, 117, 1574-1581.

[7] Nater, U. M., Rohleder, N., Gaab, J., Berger, S., Jud, A., dkk.(2004). Human salivary alpha-amilase reactivity in psychososial stress paradigm. International Journal of Psycho-Physiology, 55, 333-342. 